\title{
Evaluation of Antibiotic Resistance Patterns and Heavy Metals Tolerance of some Bacteria Isolated from Contaminated Soils and Sediments from Warri, Delta State, Nigeria.
}

\section{EGHOMWANRE, AF; OBAYAGBONA, NO; OSARENOTOR, O; ENAGBONMA BJ}

Department of Environmental Management and Toxicology, Faculty of Life Sciences, University of Benin, P.M.B 1154, Benin City, Nigeria. Correspondence Author Email: frank.eghomwanre@uniben.edu; +2348078676606.

\begin{abstract}
This work investigated the antibiotic resistance patterns and heavy metals such as Lead $(\mathrm{Pb})$, Zinc $(\mathrm{Zn})$, Cadmium $(\mathrm{Cd})$ and iron $(\mathrm{Fe})$ tolerance of selected bacteria isolated from contaminated soils and sediments around Warri area of Delta State. The heterotrophic bacterial counts for the sampled soils and sediments ranged from $1.7 \times 10^{5} \mathrm{cfu} / \mathrm{g}$ to $5.7 \times 10^{5} \mathrm{cfu} / \mathrm{g}$ for Ubeji river sediments, $1.0 \times 10^{5} \mathrm{cfu} / \mathrm{g}$ to $9.0 \times 10^{5} \mathrm{cfu} / \mathrm{g}$ for spare parts dumpsite and $1.2 \times 10^{4} \mathrm{cfu} / \mathrm{g}$ to $9.0 \times 10^{4} \mathrm{cfu} / \mathrm{g}$ for Ifie depot sites respectively. The characterized bacterial isolates included; Klebsiella sp, Bacillus subtilis, Streptococcus sp., Escherichia coli, Klebsiella mobilis and Staphylococcus sp., Micrococcus sp. and Pseudomonas aeroginosa. Bacterial isolates showed multiple drug resistance and the most resistant isolates were $S$. aureus, E. coli and P. aeroginosa while $K$. mobilis exhibited the least resistance. The tolerance of the bacterial isolates exposed to varying concentrations of $\mathrm{Pb}^{2+}, \mathrm{Cd}^{2+}, \mathrm{Fe}^{2+}$, and $\mathrm{Zn}^{2+}$ was ascertained using agar diffusion method. All the bacterial isolates exhibited varying degree of susceptibility at different concentrations of $\mathrm{Pb}$ and $\mathrm{Cd}$ while the organisms displayed abundant and moderate growth in the presence of $\mathrm{Fe}$ and $\mathrm{Zn}$ even at higher concentrations. The ability of these bacteria to resist antibiotics and heavy metal tolerance could present serious danger to the environment as the resistance genes may be transferred to surrounding wild type microbial cells.(C) JASEM
\end{abstract}

http://dx.doi.org/10.4314/jasem.v20i2.8

KEY WORDS: Heavy metals, Antibiotics resistance, tolerance, Ubeji river sediments, Warri.

\section{Introduction}

The increasing rate of industrialization in the world today is a major concern for the quality of the atmosphere, soil and water bodies (Ali et al., 2013). Human activities such as mining, use of chemical fertilizers and pesticides in agriculture, automobile mechanic activities, car battery manufacturing plants and the use of vehicles for transportation release high amounts of pollutants including heavy metals into the biosphere (Adewole and Uchegbu, 2010). Antimicrobial drug resistance in bacterial pathogens is of National and International concern (WHO, 2001). Although the misuse of antimicrobial agents is accepted as a major driving force behind the spread of resistance, the nature of this relationship is complex. Antibiotic resistance is sometimes acquired by a change in the genetic make-up of a bacterium, which can occur by either a genetic mutation or by transfer of antibiotic resistance genes between bacteria in the environment (Williams, 2002).

Although some heavy metals are essential trace elements, most are toxic at high concentrations to all organisms by forming complex compounds within the cell (Alm, 2002). Microbes are known to have evolved several mechanisms to tolerate the pressure of heavy metals by efflux, complexation, or reduction of metal ions or using them as terminal electron acceptors in anaerobic respiration (Alm, 2002). This is because heavy metals are increasingly found in habitats due to natural and industrial processes (Nies and Silver, 1995).

Efficient waste collection and specific treatment processes are generally lacking in developing countries and Nigeria in particular, dumpsites are located close to residential homes, along water courses and near water sources. The accumulation of pollutants within the environment has numerous public health implications, among which is the spread of infectious diseases (Ivanildo and Richard, 1995). This study was conducted with the aim of investigating the resistance of soil and sediment borne bacteria isolated from polluted soils and river sediments to tolerate selected heavy metals and antibiotics.

\section{MATERIALS AND METHODS}

Study area: All the sampling areas were located in Warri, Delta State, Nigeria (Fig. 1). The mechanic spare parts dumpsite is located within the vicinity of the auto mobile spare parts markets at Cemetery Road and during sampling, it was observed that spare parts from old cars are sold or dumped at the dump site (Fig 1). Other sampled areas included Ifie Depot site and Ubeji river (Fig.1). 


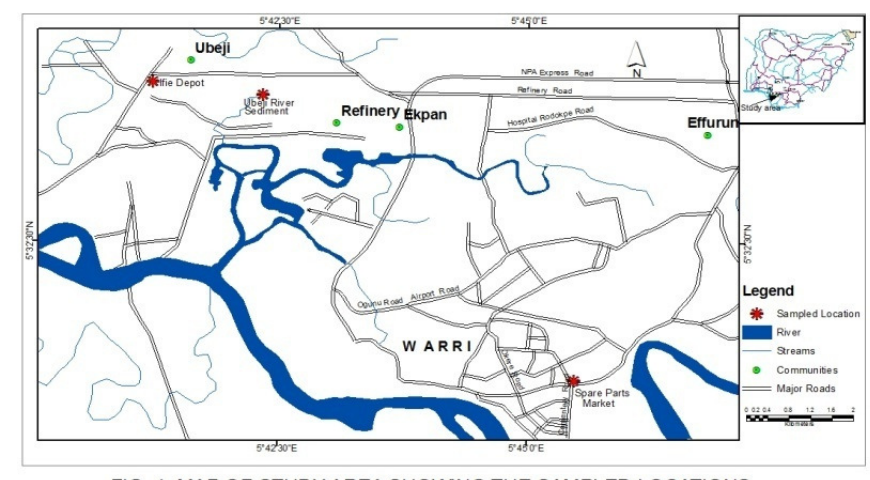

FIG. 1: MAP OF STUDY AREA SHOWING THE SAMPLED LOCATIONS

Collection of soils and sediments: A total of 6 soils and 3 sediment samples were collected from the three sampled locations in Warri, Delta State. The sites include; auto spare parts dumpsites, Ubeji river sediment and Depot sites. All the soil samples were collected using a standard soil auger, whilst the river sediment was obtained using a sediment grab. About $100 \mathrm{~g}$ of top soil sample was bored from a fallow farmland located near the spare parts market. The soil and sediment samples were kept in labeled polyethylene bags and the bags were transferred to coolers which contained ice packs. They were carried to the laboratory and stored at $4^{\circ} \mathrm{C}$ prior to microbial analysis.

Isolation and characterization of heterotrophic bacteria from both soil and sediments: Ten (10) grams of the respective samples were weighed and dissolved into $99 \mathrm{ml}$ of sterile prepared peptone water diluent under aseptic conditions. Serial fold dilutions were then made up to $10^{-6}$ and aliquots of each dilution were cultured on agar plates prepared using Nutrient Agar as general purpose culture medium (Aneja, 2003). Plating was done in duplicates and the culture plates were swirled, allowed to solidify and incubated at $35^{\circ \mathrm{C}}$ for $48 \mathrm{~h}$ and observed discrete colonies were enumerated. Unique bacterial colonies were purified and identified according to their morphological, cultural, and biochemical characteristics using the identification criteria stated by Holt et al. (1994).

Determination of the heavy metal susceptibility of the bacterial isolates: Minimum inhibitory concentrations (MICs) of the metals were determined by the Agar diffusion methods (Hassan et al., 2008) as described by Velusamy et al., (2011). The metals $\mathrm{Pb}^{2+}, \mathrm{Cd}^{2+}$, $\mathrm{Fe}^{2+}$, and $\mathrm{Zn}^{2+}$ were used as $\mathrm{PbCl}_{2}, \mathrm{CdCl}_{2}, \mathrm{FeCl}_{2}$ and $\mathrm{ZnCl}_{2}$ salts respectively. Stock solutions of the metals $(100 \mathrm{mg} / \mathrm{L})$ were prepared and Four varying concentrations $(20 \mathrm{mg} / \mathrm{L}, 15 \mathrm{mg} / \mathrm{L}$ and $10 \mathrm{mg} / \mathrm{L}$ and $5 \mathrm{mg} / \mathrm{L})$ of the respective metals were tested on the bacterial isolates. Zones of inhibitions $(\mathrm{mm})$ measured after $24 \mathrm{hr}$ of incubation using a meter rule. The control experiment was carried out by inoculating the pure isolates on basal media without the heavy metals.

Antimicrobial Susceptibility Testing: Single disc diffusion method (NCCLS, 2004) was used to examine bacterial susceptibility to antimicrobial agents. The antibiotic sensitivity discs utilized were; Streptomycin $(30 \mu \mathrm{g})$, Septrin $(15 \mu \mathrm{g})$, Erythromycin $(15 \mu \mathrm{g})$, Zinnacef $(10 \mu \mathrm{g})$, Amoxicillin (30 $\mu \mathrm{g})$, Rocephin $(10 \mu \mathrm{g})$, Ciprofloxacin $(30 \mu \mathrm{g})$, Pefloxacin $(10 \mu \mathrm{g})$, Gentamycin $(30 \mu \mathrm{g})$, Ofloxacin $(10 \mu \mathrm{g})$,

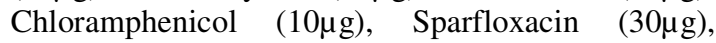

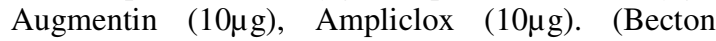
Dickinson, USA). The diameter of the inhibitory zones exhibited by the exposed bacterial isolates against the respective antibiotics was then translated into resistance and susceptibility categories according to the NCCLS, (2004).

\section{RESULT AND DISCUSSION}

Table 1 revealed mean heterotrophic bacterial counts which ranged from $1.7 \times 10^{5} \mathrm{cfu} / \mathrm{g}$ to $5.7 \times 10^{5} \mathrm{cfu} / \mathrm{g}$ for top soil collected from the depot site, $1.0 \times 10^{5} \mathrm{cfu} / \mathrm{g}$ to $9.0 \times 10^{5} \mathrm{cfu} / \mathrm{g}$ for soils obtained from the spare parts dumpsite, and $1.2 \times 10^{4} \mathrm{cfu} / \mathrm{g}$ to $9.0 \times 10^{4} \mathrm{cfu} / \mathrm{g}$ for sediments sourced from the Ubeji river. There was an increase in bacteria count in soil from depot and spare parts dumpsite when compared to the control except for sediments as shown in Table 1.The increased bacterial count which was observed in the depot site and spare parts was due to increased hydrocarbon content which is in agreement with the findings of Okerentugba and Ezeronye (2003). Gradual increase in bacterial population in contaminated soil was also reported by Amadi and Odu, (1993). There were variations in bacterial counts from the sampled locations. This could be reflective of the suspected differences in nutritional properties of the sampled soils and sediments. The presence and growth of microbes in contaminated soils from the sampled areas might suggest that the microbes have adapted to tolerate and grow in the presence of these metals.

Table 1: Total Heterotrophic Bacterial Counts (cfu/g) of soil and sediment samples

${ }^{l}$ EGHOMWANRE, AF; OBAYAGBONA, NO; OSARENOTOR, O; ENAGBONMA BJ ${ }^{4}$ 


\begin{tabular}{lllll}
\hline Location & Site1 & Site2 & Site3 & control \\
\hline Ubeji River Sediment & $3.3 \times 10^{5}$ & $1.7 \times 10^{5}$ & $5.7 \times 10^{5}$ & $5.0 \times 10^{5}$ \\
Spare parts dumpsite & $1.8 \times 10^{5}$ & $1.0 \times 10^{5}$ & $9.0 \times 10^{5}$ & $1.1 \times 10^{5}$ \\
Depot site & $2.0 \times 10^{4}$ & $9.0 \times 10^{4}$ & $1.2 \times 10^{4}$ & $1.3 \times 10^{4}$ \\
\hline
\end{tabular}

The bacterial isolates from the soils and sediments were screened for their ability to tolerate Lead, lead, cadmium, iron and zinc at four different concentrations of $20 \mathrm{mg} / \mathrm{L}, 15 \mathrm{mg} / \mathrm{L}, 10 \mathrm{mg} / \mathrm{L}$ and $5 \mathrm{mg} / \mathrm{L}$ respectively (Table 2 ). There was a decline in the growth of the organisms as concentrations of the metals increased in contrast to the situation in the control i.e., $0.0 \mathrm{mg} / \mathrm{L}$ of the metals where there was heavy growth of the bacterial isolates (Table 2) This indicates the toxic effect of the heavy metals on the growth of microorganisms as earlier stated by Badar $e t$ al. (2000).Oyetibo et al, (2010) also reported the occurrence of heavy metal resistant bacteria in contaminated soil while Badar et al. (2000) opined that contamination with a specific metal is known to increase the level of resistance of the bacterial community to that metal.

All the bacterial isolates exhibited varying degrees of susceptibility towards lead at $15 \mathrm{mg} / \mathrm{L}$ and $20 \mathrm{mg} / \mathrm{L}$ (Table 2). This trend could be explained by the fact that generally, Nies and Silver (1995) reported that lead and cadmium displayed toxic effects against microorganisms. This is in line with the findings of Mgbemena et al (2012) and also similar to a report of Rathnayake et al. (2010) which investigated the tolerance of trace metals such as $\mathrm{Cd}^{2+}, \mathrm{Cu}^{2+}$ and $\mathrm{Zn}^{2+}$ by Paenibacillus sp. and Bacillus thuringeinsis isolated from a pristine soil. Comparatively, the bacterial isolates tolerated higher levels of iron and zinc at all the concentrations than against lead and cadmium (Table 2). This phenomenon could be ascribed to potential presence of an additional high affinity ABCtransport system specific for ferrous iron $\left(\mathrm{Fe}^{2+}\right)$ encoded by ferrous ABC gene (Kammler et al., 1993). Varying microbial tolerance to heavy metals has been attributed to a variety of resistance mechanisms such as differences in uptake and/or transport of the metal while in other cases, the metal may be enzymatically transformed by oxidation, reduction, methylation or demethylation into chemical species which may be less toxic or more volatile than the parent compound. Rogers et al. (2004) opined that the transfer of antibiotic resistance gene from one bacterium to another is a reason for the high antibiotics resistance pattern in some bacteria. Lawrence (2000) reported that gene clustering on a plasmid if both or all genes clustered are useful to the bacteria, is beneficial to the survival of that bacteria and its species because those genes are more likely to be transferred together in the process of conjugation.

Table 2: Heavy metal tolerance of the exposed bacterial isolates

\begin{tabular}{|c|c|c|c|c|c|c|c|c|c|}
\hline \multirow[t]{2}{*}{ Element } & \multirow[t]{2}{*}{$\begin{array}{l}\text { Conc. } \\
(\mathrm{mg} / \mathrm{L})\end{array}$} & \multicolumn{3}{|c|}{ Zone of inhibition $(\mathrm{mm})$} & \multirow[b]{2}{*}{$\begin{array}{l}\text { Enterobacter } \\
\mathrm{sp}\end{array}$} & \multirow[b]{2}{*}{$\begin{array}{l}\text { Pseudomonas } \\
\text { Aeroginosa }\end{array}$} & \multirow[b]{2}{*}{$\begin{array}{l}\text { Micrococcus } \\
\text { sp }\end{array}$} & \multirow[b]{2}{*}{$\begin{array}{l}\text { Klebsiella } \\
\text { Mobilis }\end{array}$} & \multirow[b]{2}{*}{$\begin{array}{l}\text { Staphylococcus } \\
\text { aureus }\end{array}$} \\
\hline & & $\begin{array}{l}\text { Bacillus } \\
\text { subtilis }\end{array}$ & $\begin{array}{l}\text { Escherichia } \\
\text { coli }\end{array}$ & $\begin{array}{l}\text { Streptococcus } \\
\mathrm{sp}\end{array}$ & & & & & \\
\hline \multicolumn{10}{|c|}{ Lead $\left(\mathrm{Pb}^{2+}\right)$} \\
\hline & 20 & 15 & 13 & 10 & 16 & 18 & 15 & 17 & 13 \\
\hline & 15 & 11 & 9 & 10 & 14 & 12 & 11 & 14 & 13 \\
\hline & 10 & 9 & 6 & 7 & 8 & 9 & 6 & 11 & 7 \\
\hline & 5 & 3 & 4 & 3 & 4 & 5 & 4 & 2 & 3 \\
\hline \multirow{2}{*}{\multicolumn{10}{|c|}{ Cadmium $\left(\mathrm{Cd}^{2+}\right)$}} \\
\hline & & & & & & & & & \\
\hline & 20 & 16 & 20 & 19 & 16 & 15 & 17 & 19 & 23 \\
\hline & 15 & 12 & 12 & 8 & 15 & 14 & 11 & 12 & 10 \\
\hline & 10 & 5 & 7 & 5 & 4 & 6 & 9 & 2 & 6 \\
\hline & 5 & 4 & 3 & 4 & 3 & 5 & 4 & 6 & 8 \\
\hline \multirow{2}{*}{\multicolumn{10}{|c|}{$\operatorname{Iron}\left(\mathrm{Fe}^{2+}\right)$}} \\
\hline & & & & & & & & & \\
\hline & 20 & 8 & 4 & 4 & 2 & 10 & 8 & 8 & 6 \\
\hline & 15 & 4 & 3 & - & 4 & 8 & 6 & 2 & 4 \\
\hline & 10 & - & - & - & 2 & 4 & 5 & 3 & 4 \\
\hline & 5 & - & - & - & - & - & - & - & - \\
\hline & 0 & - & - & - & - & - & - & - & - \\
\hline \multicolumn{10}{|c|}{$\operatorname{Zinc}\left(\mathrm{Zn}^{2+}\right)$} \\
\hline & 20 & 11 & 8 & 9 & 8 & 7 & 12 & 11 & 8 \\
\hline & 15 & 6 & 4 & - & 4 & 5 & 2 & 4 & 4 \\
\hline & 10 & - & - & - & - & - & - & - & - \\
\hline & 5 & - & - & - & - & - & - & - & - \\
\hline & 0 & - & - & - & - & - & - & - & - \\
\hline
\end{tabular}

Table 3: Antibiotic susceptibility and resistance pattern of the bacterial isolates

${ }^{1}$ EGHOMWANRE, AF; OBAYAGBONA, NO; OSARENOTOR, O; ENAGBONMA BJ ${ }^{4}$ 


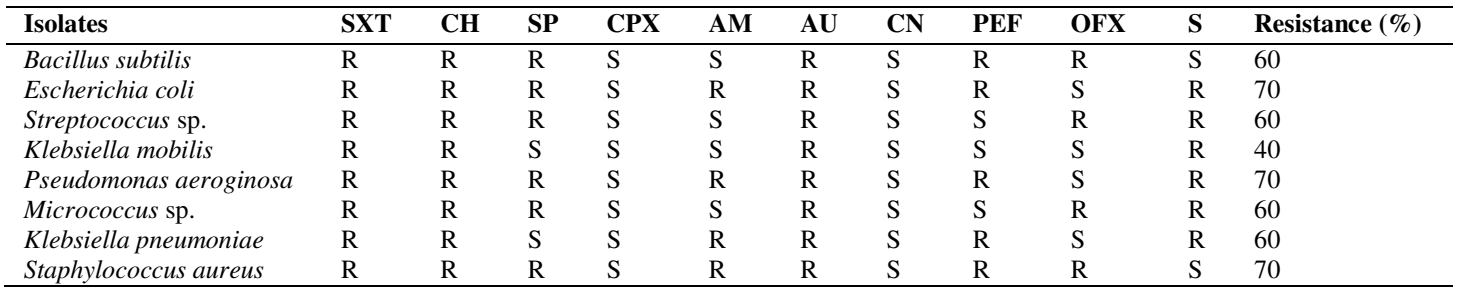

KEY: SXT=Septrin, $\mathrm{CH}=$ Chloramphenicol, $\mathrm{SP}=$ Sparfloxacin, $\mathrm{CPX}=$ Ciprofloxacin, $\mathrm{AM}=\mathrm{Amoxicillin}, \mathrm{AU}=$ Augmentin, $\mathrm{CN}=$ Gentamycin, $\mathrm{PEF}=$ Pefloxacin, $\mathrm{OFX}=$ Ofloxacin, $\mathrm{S}=$ Streptomycin

The antibiogram profile of the test bacterial cultures revealed that the all the soil and sediment borne bacterial isolates were multi drug resistant (Table 4). This trend could be attributed to the production of enzymes which could inactivate or modify the specific antibiotics and changes in bacterial cell membrane, modification of target site and development of metabolic pathways by bacteria (Kim et al., 2006). Oyetibo et al (2010) found that heavy metal resistant bacterial isolates; Pseudomonas sp., Aeromonas sp., Bacillus sp. Micrococcus sp., Proteus sp .and E. coli exhibited high tolerance to gentamycin $(77.7 \%)$, rifampicin $(66.0 \%)$, and ofloxacin $(57.3 \%)$. The resistance of the organisms to the antibiotics confirms the correlation between resistance metal ions and antibiotics. This has also been reported by Rajbanshi, (2008) in bacterial species from different sources. Nies, 2003 have speculated and have shown this to be as a result of the likelihood that resistance genes to both antibiotics and heavy metals could be closely located on the same plasmid in bacteria and are thus more likely to be transferred together in the environment.

Conclusion: This study therefore revealed the presence of iron, zinc tolerant and multi drug resistant bacteria in the sampled soils and sediments collected from anthropogenically disturbed edaphic and aquatic areas in Warri, Delta State. It is recommended that further studies that would investigate the actual physiological mechanisms responsible for the ability of these bacteria to tolerate varying heavy metal concentrations and the harbored genetic elements causing the multiple antibiotic resistance trend should be undertaken.

\section{REFERENCES}

Adewole, M. B. and Uchegbu, L. U. (2010). Properties of soils and plants uptake within the vicinity of selected automobile workshops in Ile-Ife Southwestern, Nigeria. Ethiopian J. Environ. Stud. Manage. 3: 31-35.

Ali, S., Sardar, K., Hameed, S., Afzal, S., Fatima, S., Shakoor, B. M., Bharwana, S. A. and Tauqeer, H. M. (2013). Heavy metals contamination and what are the impacts on living organisms. Greener $\boldsymbol{J}$. Environ. Manage. and Pub S. 2: 172-179.
Alm, E.(2002).Implications of microbial heavy metal tolerance in the environment. Rev Undergraduates Res- Issue 2.

Amadi, A., \& Odu, C.T.I. (2003). Effect of simulated chemical demulsifier contamination of soil on carbon dioxide evaluation and shift in microbial population in a fresh water mangrove ecosystem. Inter J. Biochem, 2(1-2):97-99.

Aneja KR. (2003). Experiments in Microbiology,Plant Pathology and Biotechnology. Fourth Edition. New Delhi: New Age Pub. 606 pp.

Badar, U., R., Abbas, M. and Ahmed, N.(2000). Characterization of copper and chromate resistant bacteria isolated from Karachi tanneries effluents. J. Ind. Env. Bio, 39: 43-54.

Hassan SHA, RNN Abskharon, SMF Gad El-Rab and AAM Shoreit, 2008. Isolation and characterization of heavy metal resistant strain of Pseudomonas aeruginosa isolated from polluted sites in Assiut, Egypt. J Basic Microbiol, 48: 168176.

Holt J.G., Krieg N.R., Senath P.H.A., Stanley J.T., and Williams S.T.(1994) Bergey's Manual of Determinative Bacteriology, $9^{\text {th }}$ ed.; Williams and Wilkins, Baltimore.

Ivanildo, H and Richard, H (1995).Water Pollution Control. A guide to the use of water quality management principles: United Nations Environmental Programme(UNEP). St Edmunsbury Publications, Suffolk, Great Britain. Pp 34.

Kammler, M., Schon, C. and Hantke, K.(1993).Characterization of the ferrous ion uptake system of Escherichia coli. $J$. Bacteriol.175: 6212-6219.

Kim, D.J., Lee, D.I., Keller, J., (2006). Effects of temperature and free Ammonia On nitrification and nitrite accumulation. In landfill leachate and analysis of its nitrifying Bactrerial community by FISH. Bioresour Technol, 97:459-468. 
Lawrence, J.G., (2000). Clustering of antibiotics resistance genes among bacteria isolated from a water distribution system. Can. J. Microbiol, 41:642-646.

Mgbemena, C. I., Nnokwe, J. C., Adjeroh, L.A. and Onyemekara, N. N. (2012). Resistance of bacteria isolated from Otamiri River to heavy metals and some selected antibiotics. Curr. Res. J. Biol. Sci, 4: 551-556.

National Committee for Clinical Laboratory Standards (NCCLS) (2004). Methods for dilution antimicrobial susceptibility tests for bacteria that grow aerobically: Approved

Nies, D.H. and Silver, S. (1995). Ion efflux systems involved in bacterial metal resistances. J. Ind.

Microbiol, 14: 186-199.

Nies, D.H., 2003. Efflux-mediated heavy metal resistance in prokaryotes.FEMS Microbiol Rev, 27: $313-339$

Okerentugba, P.O. \& Ezeronye, O. U. (2003). Petroleum Degrading Potential of Single and Mixed Microbial Cultures Isolated From Rivers and Refinery Effluents in Nigeria. $\boldsymbol{A} \boldsymbol{f r} \boldsymbol{J}$. Biotechnol, 2(9), 288-292.

Oyetibo, G. O., Ilori, M. O., Adebusoye, S. A., Obayori, O. S. and Amund O. O. (2010). Bacteria with dual resistance to elevated concentrations of heavy metals and antibiotics in Nigeria in contaminated systems. Environ Monit Assess 168: 305-314.
Rajbanshi, A.,(2008). Study on heavy metal resistance bacteria in guesswork sewage treatment plant. Our Nature 6: 52-57.

Rathnayake, IVN, M Megharaj, N Bolan and R Naidu, 2010. Tolerance of heavy metals by Gram positive soil bacteria. Inter J. Civil Env Eng, 2: 191-195.

Rogers SD, Bhave MR, Mercer JF, Camakaris J, Lee BT. (2004). Cloning and characterization of cut E, a gene involved in copper transport in Escherichia coli. J. Bacteriol, 173: 6742-6748.

Velusamy P, YM Awad, SAM Abd El-Azeem and YS Ok, 2011. Screening of heavy metal resistant bacteria isolated from hydrocarbon contaminated soil in Korea. J. Agri Life Environ Sci, 23: 40-43.

Williams, S. (2002). Antibiotic resistance: Not just for people anymore. J. Young Investigators, 3: 1-4.

World Health Organization (2001).WHO global strategy for containment of Antimicrobial resistance. Geneva. 